\title{
Mineral, Vitamin and Antinutritional Content of African Breadfruit (Treculia africana) Seeds Processed with Alum and Trona
}

\author{
Abiodun A. Olapade, Uchenna C. Umeonuorah \\ Department of Food Technology, Faculty of Technology, University of Ibadan, Ibadan, Nigeria.
}

\begin{abstract}
African breadfruit seed (ABFS) like any other legumes takes longer time to prepare for consumption, hence its traditional preparation involves use of alum and Trona. In this study, ABFS was steeped with different concentrations of alum $(0,1.0,1.5$ and $2.0 \%)$ for $24 \mathrm{~h}$. The seeds were parboiled, dehulled and then cooked with different Trona concentrations (0, 1.0, 1.5 and 2.0\%) for $90 \mathrm{~min}$. The minerals, vitamins and antinutritional properties of these samples were each analyzed alongside the control (raw dehulled ABFS). The results obtained showed that significant differences $(P<0.05)$ exist between the control and the processed samples as well as among the processes samples. ABFS sample steeped without Alum had the highest mineral and vitamin contents. The raw ABFS sample had the highest values for oxalate (0.21 \pm 0.01$)$, tannin $(0.06 \pm 0.01)$, saponin,

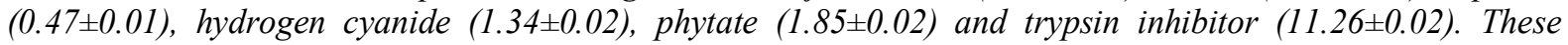
antinutrients reduced to safe consumption levels in the processed samples. Cooking ABFS with Trona had significant effect on anti-nutrient reduction which enhanced the nutritional quality of ABFS.
\end{abstract}

Keywords: Treculia africana, African breadfruit seed, Alum, Trona, Steeping, Cooking, Chemical quality.

\section{Introduction}

Treculia Africana Decne popularly known as African breadfruit or wild jack fruit in some area, is neglected and under exploited tropical tree belonging to the taxonomic family Moracceae [1]. According to [2], it is a common forest tree known by various tribal names in Nigeria such as "Ukwa" (Igbo), "afon" (Yoruba), "barafuta" (Hausa), "Ize" (Benin) "eyo" (Igala) and "edikang" (Efik). The tree crop is widely grown in the Southern States of Nigeria where it serves as low cost meat substitute for poor populace [3, 4]. The plant produces large, usually round, compound fruits covered with pointed outgrowths and the seeds are buried in spongy pulp of the fruits. Nwokolo [5] reported that there is an increased interest in African breadfruit seed, which is an important food item among the Igbo tribal group of South-Eastern Nigeria.

The seeds are seldom eaten raw but can be baked, boiled, roasted and fried before consumption, or they can also be ground into flour which can be used as a substitute to wheat flour in bakery products [6]. Ijeh et al. [7] also reported that the seeds of Treculia Africana are eaten as a delicacy in the South-Eastern part of Nigeria. Diverse food forms could be produced from the seeds on the basis of custom, tradition and ethnic background. The seed is variously cooked as porridge alone or mixed with other food stuff such as sorghum [8], or roasted and sold with palm kernel (Elaeis guineensis) as roadside snack. Sunday et al. [9] reported that pastries, weaning foods, breakfast cereals and beverages could be developed from African breadfruit seeds. Onyekwelu and Fayose [10] reported that the seed kernel was used in preparing pudding, as a thickener in traditional soups and in the manufacture of food products such as flour for bread, beverages and weaning food for children. In the past the consumption was limited to poor village dwellers for whom it supplemented their diets during times of food scarcity and substituted the more expensive rice during festivals and other ceremonies on the basis of tradition and cost [11]. But today, African breadfruit has become a delicacy and a specialized meal not only for the rich and the urban dwellers in Nigeria but has also become a source of foreign exchange as the dehulled seeds are sun-dried and exported to cater for the African consumer interests overseas.

The seeds are highly nutritious and constitute a cheap source of vitamins, minerals, proteins, carbohydrate and fats. Proximate analysis showed that the seeds contain $17-23 \%$ crude protein, $11 \%$ crude fat and other essential vitamins and minerals [12]. Legumes generally have been reported to contain some antinutrients such as oxalate, tannin, hydrogen cyanide, phytates [13], which interfere with digestive processes and prevent efficient utilization of their nutrients especially proteins. Different methods of processing such as fermentation, boiling, autoclaving and germination have been reported as effective methods of reducing antinutritional factors in legumes. Fasasi et al. [14] reported the presence of some antinutritional factors like hydrocyanic acid, oxalates, phytates and tannins in African breadfruit seeds. The presence of these antinutritional factors limits the use of these crops. Consumption of foods containing these factors reduces nutrient utilization, feed efficiency and productivity. At high levels of intake, toxicity ensues and in extreme cases, 
death. However, the activity of these compounds can be removed or reduced by dehulling, soaking, boiling, toasting and fermenting [15].

Oyetayo and Omenwa [16] reported that in the Southern part of Nigeria, Treculia africana seeds are normally processed for consumption by boiling with Trona. Trona locally known as "kanwa" is an alkaline salt (sodium sesquicarbonate) commonly used as indigenous tenderizer and flavouring agents in various foods [17, 18]. Alum known as potash alum is used in processing of this seed. Nwankwo et al. [19] studied the effect of alum on the proximate composition of raw African breadfruit. The effect of use of Trona on some chemical properties, microbiological and sensory qualities of cooked cowpea and 'masa' (a traditional food made from rice grain) has been reported [18]. Reduction to a safe level of the antinutritional factor is essential to improve the nutritional quality of ABFS and effectively utilize its full potentials in human food. Information regarding the effect of traditional processing methods with Alum and Trona on the levels of minerals, vitamins some antinutritional factor in ABFS is not readily available in literature. Therefore, the aim of this study is to investigate minerals, vitamins and anti-nutritional factors inherent in raw and processed African breadfruit seeds as affected by the concentration of Alum and Trona used.

\section{Materials and Methods}

\section{Materials Collection}

Mature African breadfruits used for this study were procured from a farm at Oboro town, Umuahia Abia State, where the fruits are abundance and cheap. Alum and Trona used for the processing were also bought at the Oboro town market. The fruits were authenticated at the Agronomy Department of National Root Crops Research Institute (NRCRI) Umudike, Abia State. All the chemicals used in this study were of analytical grade. The analysis was carried at the Multidisciplinary Central Research Laboratory of the University and Central Laboratory of NRCRI Umudike. The fruits were processed within $24 \mathrm{~h}$ after sample procurement.

\section{Sample Preparation}

The fruits were processed following the traditional techniques as practiced by the people of Oboro town. The method involved extraction of the African breadfruit seeds from the pulpy fruits using the flowing water with sand, sponge in locally made basket until the slimness of the husk was reduced considerably. The seeds were sorted to remove extraneous materials such as dirt, shriveled and infected seeds. The wholesome seeds obtained were washed with clean water, weighed out into five equal portions of $1 \mathrm{~kg}$ each and coded as $\mathrm{ABF}, \mathrm{ABK}, \mathrm{ABR}, \mathrm{ABS}$, and $\mathrm{ABT}$. $\mathrm{ABF}$ was dehulled without soaking to serve as the control sample, while the remaining samples $(\mathrm{ABK}, \mathrm{ABR}, \mathrm{ABS}$, and $\mathrm{ABT})$ were each steeped in distilled water 1: $10(\mathrm{w} / \mathrm{v})($ African breadfruit seeds: Water) for $24 \mathrm{~h}$ with addition of $0,1.0,1.5$ and $2.0 \%$ Alum respectively by modified method of steeping reported by Nwosu et al. (2012). These four samples were parboiled with distilled water in 1: 10 $(\mathrm{w} / \mathrm{v})$ for $15 \mathrm{~min}$ at $100 \mathrm{C}$, after which the water was drained and the parboiled seeds were allowed to cool, manually dehulled and washed with distilled water. These samples after washing, were cooked separately with distilled water in 1: $10(\mathrm{w} / \mathrm{v})$ (African breadfruit seeds: Water) for $90 \mathrm{~min}$ at $100 \mathrm{C}$ with addition of $0,1.0,1.5$ and $2.0 \%$ Trona respectively, and coded as $\mathrm{ABK}^{1}, \mathrm{ABR}^{1}, \mathrm{ABS}^{1}$, and $\mathrm{ABT}^{1}$ respectively.

\section{Mineral Composition Analysis}

The Methods described by Obasi and Wogu [20] were used in mineral determination. The samples were digested by wet-digestion method using combination of Percholic acid, nitric acid and sulphuric acid. The digest so obtained was used for the various analyses. De-ionized water was used to avoid interferences from the minerals that may be contained in the water. The calcium, potassium and sodium were determined on the Jenway digital Flame Photometer (PFP7 Model) using the filter corresponding to each mineral element. The phosphorus was obtained by taking the absorbance of the solution on a Spectrophotometer (Jenway Metrohm Spectronic 21D Models) at a wavelength of $470 \mathrm{~nm}$. Each of the trace mineral elements was read at their respective wavelengths with their respective hollow cathode lamps using appropriate fuel and oxidant combination on a Perkin-Elmer Model 403 Atomic Absorption Spectrophotometer (AAS).

\section{Determination of Vitamins}

Vitamins A, B1, B2 and B3 were determined using the methods of extraction described by Okwu [21] and Okwu and Ndu [22]. The absorbance of vitamin A at a wavelength of $328 \mathrm{~nm}$, vitamin B1 at a wavelength $360 \mathrm{~nm}$, vitamin B2 at $510 \mathrm{~nm}$ wavelength and vitamin B3 at $470 \mathrm{~nm}$ wavelength were determined using Jenway Spectrophotometer (Metrohm Spectronic 21D Model). Vitamins C was determined using the method based on the reduction of the dye (2,6 -dichlorophenolindophenol). 


\section{Determination of Antinutrients.}

The tannin, phytates and hydrogen cyanide contents were determined as reported by Mbaeyi and Onweluzo [23], while oxalate and saponin were determined using the methods of AOAC [24]. Trypsin inhibitor activity was determined according to the modified method of Kakade et al. [25].

\section{Statistical Analysis.}

All the data generated from analytical determinations were analyzed and the descriptive statistics presented as mean \pm standard deviation of the three determinations. Differences between means were separated using statistical analysis of variance (ANOVA) and multiple comparison test using Duncan's Multiple Range Test (DMRT) with the least significant difference fixed at 0.05 . Analyses were done using statistical software package, SPSS (windows version 20.0).

\section{Mineral Contents}

\section{Results and Discussion}

Table 1 showed the result of the mineral contents of the raw and processed African breadfruit seeds (ABFS). The result showed that there were significant differences $(\mathrm{P}<0.05)$ in the sodium, potassium, calcium, phosphorus, magnesium, iron, zinc, copper and manganese contents of the raw and processed ABFS. The significant differences observed in the samples are due to the effect of the processing. The raw and processed ABFS are richer in sodium, potassium and phosphorus than calcium, magnesium, iron, zinc, copper and manganese. Generally, mineral contents of the ABFS steeped without Alum had the highest mineral contents: sodium $(390.41 \pm 0.03 \mathrm{mg} / 100 \mathrm{~g})$, potassium $(588.62 \pm 0.02 \mathrm{mg} / 100 \mathrm{~g})$, calcium $(6.41 \pm 0.02 \mathrm{mg} / 100 \mathrm{~g})$, phosphorus $(590.64 \pm 0.02 \mathrm{mg} / 100 \mathrm{~g})$, magnesium $(2.45 \pm 0.01 \mathrm{mg} / 100 \mathrm{~g})$, iron $(2.76 \pm 0.03 \mathrm{mg} / 100 \mathrm{~g})$, zinc $(8.68 \pm 0.02 \mathrm{mg} / 100 \mathrm{~g})$, copper $(3.86 \pm 0.03 \mathrm{mg} / 100 \mathrm{~g})$ and manganese $(3.49 \pm 0.01 \mathrm{mg} / 100 \mathrm{~g})$. The increment over the values for raw sample could be attributed to fermentation and hydrolysis of the antinutrients during steeping. The antinutrients leached into the soaking water thereby decreasing their concentration in the ABFS sample, thus releasing more minerals from their originally bound complexes due to their decreased concentration, as these antinutrients bind with the minerals. The increments in the mineral content is confirmed by the work of Obizoba and Egbuna [26], who reported increment in the mineral content of bambara nut after fermentation of the soaked seeds.

The Sodium content of the raw ABFS sample under study was $386.60 \pm 0.02 \mathrm{mg} / 100 \mathrm{~g}$, which was extremely higher than that of Osabor et al. [27] who reported $7.10 \pm 0.10 \mathrm{mg} / 100 \mathrm{~g}$ as the sodium content of the raw African breadfruit seed. The difference in the sodium contents could be as a result of differences in cultivar and soil composition and the rate of uptake of the minerals by the plant [28]. Also, mineral content depends on the species, soil type, climatic condition, season, water source and cultural practices adopted during planting [29]. Sodium is needed by the body for the maintenance of osmotic pressure, acid-base balance, absorption of glucose and transmission of impulse [30]. The Sodium content of the ABFS samples soaked in Alum concentrations of $0,1.0,1.5$ and $2.0 \%$ for $24 \mathrm{~h}$ were found to be $390.41 \pm 0.03 \mathrm{mg} / 100 \mathrm{~g}, 381.64 \pm 0.01 \mathrm{mg} / 100 \mathrm{~g}$, $374.18 \pm 0.00 \mathrm{mg} / 100 \mathrm{~g}$ and $370.03 \pm 0.01 \mathrm{mg} / 100 \mathrm{~g}$ respectively. These samples when cooked with $0,1.0,1.5$ and $2.0 \%$ Trona concentrations for 90 minutes had sodium contents of $384.01 \pm 0.02 \mathrm{mg} / 100 \mathrm{~g}, 369.20 \pm 0.02 \mathrm{mg} / 100 \mathrm{~g}$, $366.61 \pm 0.03 \mathrm{mg} / 100 \mathrm{~g}$ and $365.84 \pm 0.03$ respectively (Table 1 ). Trona as a catalyst has helped in the breaking down of the cell wall of the ABFS samples thereby creating large surface area which leads to the loss of mineral during cooking. Omafuvbe and Oyedapo [31] and Omafuvbe et al. [32] had reported similar result that large surface area aided the loss of mineral content during boiling of African oil bean (Pentaclethra macrophylla) and soy bean seeds.

The raw ABFS sample under study contained $570.19 \pm 0.03 \mathrm{mg} / 100 \mathrm{~g}$ of potassium whereas, samples steeped in $0,1.0,1.5$ and $2.0 \%$ Alum concentration for $24 \mathrm{~h}$ were found to have the potassium contents of $588.62 \pm 0.02 \mathrm{mg} / 100 \mathrm{~g}, 556.31 \pm 0.00 \mathrm{mg} / 100 \mathrm{~g}, 553.66 \pm 0.01 \mathrm{mg} / 100 \mathrm{~g}$ and $550.80 \pm 0.02$ respectively, these samples when cooked with $0,1.0,1.5$ and $2.0 \%$ Trona concentrations for $90 \mathrm{~min}$ had potassium contents of $546.41 \pm 0.02 \mathrm{mg} / 100 \mathrm{~g}, 521.43 \pm 0.02 \mathrm{mg} / 100 \mathrm{~g}, 520.59 \pm 0.01 \mathrm{mg} / 100 \mathrm{~g}$ and $511.23 \pm 0.03 \mathrm{mg} / 100 \mathrm{~g}$ respectively. The value of potassium content of the raw ABFS sample in the present study is closer to the value $(587 \pm$ $0.02 \mathrm{mg} / 100 \mathrm{~g}$ ) reported by Osabor et al. [27] for potassium content of raw ABFS. Similarly, the results of the other minerals contents of the ABFS samples (phosphorus, magnesium, iron, zinc, copper and manganese) under study followed the same trend. The mineral contents of the control ABFS sample in the present study were slightly higher: phosphorus $(588.45 \pm 0.02 \mathrm{mg} / 100 \mathrm{mg})$, magnesium $(2.40 \pm 0.02 \mathrm{mg} / 100 \mathrm{mg})$, iron $(2.70 \pm 0.02 \mathrm{mg} / 100 \mathrm{mg})$, zinc $(8.59 \pm 0.01 \mathrm{mg} / 100 \mathrm{mg})$, copper $(3.75 \pm 0.02 \mathrm{mg} / 100 \mathrm{mg})$, and manganese $\left(3.44 \pm 0.01 \mathrm{mg} / 100 \mathrm{mg}\right.$ ) than the Alum and Trona processed ABFS samples. Sample ABT ${ }^{1}$ (ABFS Sample steeped in $2.0 \%$ Alum concentration and cooked with $2 \%$ Trona concentration) had the least mineral contents of $452.56 \pm 0.03 \mathrm{mg} / 100 \mathrm{mg}, 1.90 \pm 0.01 \mathrm{mg} / 100 \mathrm{mg}, 2.44 \pm 0.02 \mathrm{mg} / 100 \mathrm{mg}, 8.40 \pm 0.01 \mathrm{mg} / 100 \mathrm{mg}, 2.42 \pm 0.01 \mathrm{mg} / 100 \mathrm{mg}$ and $2.94 \pm 0.02 \mathrm{mg} / 100 \mathrm{mg}$ for phosphorus, magnesium, iron, zinc, copper and manganese respectively. The decrease in the mineral contents of the Alum and Trona processed ABFS samples as the concentration of Alum 
and Trona increased could be attributed to the leaching of these minerals into the processing water as well as high cooking temperature which could have caused loss of some of these minerals.

\section{Vitamin Contents}

The result of the vitamin contents determination carried on the ABFS samples showed that there were significant differences $(\mathrm{P}<0.05)$ on the vitamins $\mathrm{A}, \mathrm{B}_{1}, \mathrm{~B}_{2}, \mathrm{~B}_{3}$ and $\mathrm{C}$ contents of the raw and processed $\mathrm{ABFS}$ as well as among the processed samples (Table 2). The significant differences observed in the samples were due to the effect of the processing. The vitamin A content of the raw African breadfruit seed was $20.37 \pm 0.01 \mu \mathrm{g} / 100 \mathrm{~g}$. However, vitamin A content of the sample ABK (Sample steeped with $0.00 \%$ Alum) was found to be higher $(20.74 \pm 0.01 \mu \mathrm{g} / 100 \mathrm{~g})$ than other samples steeped in $1.0,1.5$ and $2.0 \%$ with the vitamin A contents of $20.07 \pm 0.07 \mu \mathrm{g} / 100 \mathrm{~g}, 19.66 \pm 0.02 \mu \mathrm{g} / 100 \mathrm{~g}$ and $19.01 \pm 0.00 \mu \mathrm{g} / 100 \mathrm{~g}$ respectively. The decrease in vitamin A contents as the concentration of the Alum increased might have resulted from increased chemical reactions generally by the leaching into the steeping water, while the higher value $(20.74 \pm 0.02 \mu \mathrm{g} / 100 \mathrm{~g})$ for the sample steeped in $0.0 \%$ Alum concentration for 24 hours is expected as steeping for 24 hours (fermentation) has been reported to increase vitamin content of foods [33]. The vitamin A contents of the sample were found to be decreased more after being cooked with Trona solutions of $0,1.0,1.5$ and $2.0 \%$ for 90 minutes given vitamin A contents of $18.32 \pm 0.02 \mu \mathrm{g} / 100 \mathrm{~g}, 15.42 \pm 0.02 \mu \mathrm{g} / 100 \mathrm{~g}, 15.08 \pm 0.02 \mu \mathrm{g} / 100 \mathrm{~g}$ and $14.84 \pm 0.03 \mu \mathrm{g} / 100 \mathrm{~g}$ respectively (Table 2). The decrease may be attributed to the high cell damage due to the coupled effects of high Trona concentration and the long cooking time which causes the Vitamins A to be leached easily into the cooking water. Also, Heat, light, exposure to the air, cooking in water and alkalinity are all factors that can destroy vitamins. Badejo [34] reported that losses of vitamins occur during processing operations such as milling, soaking, trimming, blanching, etc, which is a case in the present study .

Similar results were obtained for vitamins $B_{1}(0.20 \pm 0.01 \mathrm{mg} / 100 \mathrm{mg}), B_{2}(12.45 \pm 0.01 \mathrm{mg} / 100 \mathrm{mg}), B_{3}$ $(18.15 \pm 0.02 \mathrm{mg} / 100 \mathrm{~g})$ and $\mathrm{C}(2.29 \pm 0.01 \mathrm{mg} / 100 \mathrm{mg})$ content of the raw ABFS sample were found to be lower than the samples ABFS sample steeped in $0 \%$ Alum concentration: Vitamins $B_{1}(0.24 \pm 0.02 \mathrm{mg} / 100 \mathrm{mg}), B_{2}$ $(12.73 \pm 0.02 \mathrm{mg} / 100 \mathrm{mg}), B_{3}(18.36 \pm 0.02 \mathrm{mg} / 100 \mathrm{~g})$ and $\mathrm{C}(2.48 \pm 0.02 \mathrm{mg} / 100 \mathrm{mg})$ contents. The decrease in Vitamins $\mathrm{B}_{1}, \mathrm{~B}_{2}, \mathrm{~B}_{3}$ and $\mathrm{C}$ contents as the concentrations of the Alum and Trona increased might have resulted from increased chemical reactions which lead to the high cell damage due to the coupled effects of high trona concentration and the long cooking time which causes these Vitamins to be leached easily into the processing water. Also, Heat, light, exposure to the air, cooking in water and alkalinity are all factors that can destroy vitamins. Some of the water soluble vitamins are readily destroyed during boiling and cooking.

\section{Antinutritional Factors}

The result of the antinutritional factor analysis carried out on the ABFS samples showed that there were significant differences $(\mathrm{P}<0.05)$ between the raw ABFS (control sample) processed samples in all the antinutritional factors (oxalate, tannin, saponin, hydrogen cyanide, phytate and trypsin inhibitor) analyzed (Table 3). This could be attributed to the effects of the processing. However, there were no significant differences $(\mathrm{P}<0.05)$ among the oxalate contents of the Alum and Trona processed ABFS samples. Similar result was also observed in the Tannin contents of the Alum and Trona processed samples. The oxalate content of the raw ABFS sample $(0.21 \pm 0.01 \%)$ was higher than the value reported for the raw Treculia africana seeds $(0.03 \pm$ $0.11 \%$ ) by Osabor et al. [27]. The samples steeped in $0,1.0,1.5$ and $2.0 \%$ Alum solutions for 24 hours were found to have the oxalate contents of $0.16 \pm 0.05 \%, 0.15 \pm 0.01 \%, 0.15 \pm 0.01 \%$ and $0.14 \pm 0.01 \%$ respectively. When these samples were cooked with $0.0 \%, 1.0 \%, 1.5 \%$ and $2.0 \%$ Trona solutions for 90 minutes, the oxalate contents were $0.13 \pm 0.01 \%, 0.14 \pm 0.01 \%, 0.13 \pm 0.01 \%$ and $0.14 \pm 0.05 \%$ respectively (Table 3 ). The decrease in the value of the oxalate contents of the processed ABFS samples could be attributed to the leaching out of oxalate in the processing water. It could also be that some oxalate had been destroyed by high cooking time ( 90 minutes). Nwosu, et al. [35] reported similar result that processing of African yam bean (Sphenostylis sternocarpa) with Alum and Trona had effect on the anti nutritional properties of this bean.

The Tannin contents of the raw ABFS (control) sample was highest $(0.06 \pm 0.01 \%)$ while the processed ABFS samples had lower Tannin contents ranged from $0.01 \pm 0.00 \%$ to $0.02 \pm 0.02 \%$ (Table 3). The tannin content $(0.06 \pm 0.00 \%)$ of the raw ABFS sample reported in the present study were lower when compared with the value $(0.14 \pm 0.00 \%)$ reported by Ijeh et al. [7] and $(26.45 \mathrm{mg} / 100 \mathrm{~g})$ reported by Ugwu and Oranye [15]. The differences observed in the tannin contents of these raw ABFS samples could be attributable to the species or variety of African breadfruit seed used. The reduction observed could be as result of leaching and/or the effect of the heat on the heat labile tannins contained in the ABFS samples. This agrees with the fact that tannins are polyphenols and polyphenolic compounds which are soluble in water [15], are mostly located in the seed coat and therefore their reduction during steeping (fermentation) and cooking may be attributed to leaching out of the phenol. Ikemefuna et al. [36] also reported that soaking and fermentation decreases the tannins content in 
legumes. Nwosu et al. [37] reported similar result that the Tannin content of raw African yam bean $(0.41 \%)$ after being soaked with $1.0 \%$ Alum solution for 24 hours was reduced to $(0.194 \%)$.

Saponin content was highest $(0.47 \pm 0.01 \%)$ in the raw ABFS sample while the processed samples had lower saponin contents of between $0.22 \pm 0.00 \%$ and $0.25 \pm 0.01 \%$. The value of the saponin content of the raw ABFS samples $(0.47 \pm 0.01 \%)$ obtained from this study was closer to the value reported for the tannin content of raw Treculia africana seeds $(0.37 \pm 0.03 \%)$ by Ijeh et al. [7]. Samples steeped in $0,1.0,1.5$ and $2.0 \%$ Alum concentrations for 24 hours had saponin contents of $0.22 \pm 0.01 \%, 0.22 \pm 0.00 \%, 0.22 \pm 0.02 \%$ and $0.22 \pm 0.05 \%$. The reduction observed could be as result of leaching and/or the effect of the heat on the heat labile tannins contained in the ABFS samples. It was observed that saponin present in the raw ABFS sample was reduced to minimal level when steeped and cooked with different concentrations of Alum and Trona. This result confirms with the report of Onimawo and Akubor [38], that alkaline washing or dry scouring and abrasive dehulling have been suggested as techniques for saponin reductions in legumes. Saponins are not destroyed during cooking [37]. However, Onimawo and Akubor [38] reported that trace elements of saponins are nutritionally beneficial because of their hypocholestorolemic activity (cholesterol lowering). Saponin is another antinutritional factor whose toxicological effects should be balanced with its benefits. However, these samples when cooked with Trona solutions of $0,1.0,1.5$ and $2.0 \%$ for 90 minutes, had saponin contents of $0.24 \pm 0.01 \%, 0.25 \pm 0.01 \%$, $0.25 \pm 0.05 \%$ and $0.25 \pm 0.01 \%$ respectively. Nwosu et al. [37] reported similar result that the saponin contents of raw African yam bean $(0.57 \%)$ after being soaked with $0.25-75 \%$ Trona solution for $24-48$ hours was increased to $(0.63-0.73 \%)$.

Hydrogen cyanide was highest $(1.34 \pm 0.02 \%)$ in the raw ABFS sample and lowest $(0.01 \pm 0.02 \%)$ in the sample cooked with $2.0 \%$ Trona solution. The value of the hydrogen cyanide content of the raw ABFS samples $(0.47 \pm 0.01 \%)$ obtained from this study was lower to the value of hydrogen cyanide reported for raw Treculia africana seeds $(26.45 \mathrm{mg} / \mathrm{kg})$ by Ugwu and Oranye [15] but higher than the value $(0.06 \pm 0.12 \mathrm{mg} / 100 \mathrm{~g})$ reported by Osabor et al. [27]. The differences observed may be due to the species or variety of African breadfruit seed used. Samples steeped in $0,1.0,1.5$ and $2.0 \%$ Alum concentrations for 24 hours, had hydrogen cyanide contents of $1.08 \pm 0.02 \%, 1.06 \pm 0.01 \%, 1.07 \pm 0.01 \%$ and $1.07 \pm 0.01 \%$ respectively. There is no significant difference $(\mathrm{P}<0.05)$ in hydrogen cyanide content of the Alum processed samples. The value of the hydrogen cyanide of the these samples were drastically reduced further to a non significant values when cooked with $0,1.0,1.5$ and $2.0 \%$ Trona solutions for 90 minutes giving the hydrogen cyanide contents of $0.07 \pm 0.02 \%, 0.04 \pm 0.01 \%$, $0.02 \pm 0.01 \%$ and $0.01 \pm 0.02 \%$ respectively. These values are very close to the acceptable safe standard of hydrogen cyanide (25-30ppm) in human being as reported by Onimawo and Egbekun [30].

In terms of the phytate contents of the ABFS samples, the control sample had the highest phytate content of $1.85 \pm 0.02 \%$. The value of the raw ABFS sample was slightly lower than the values reported for the phytate content of raw Treculia africana seeds $(2.16 \mathrm{mg} / 100 \mathrm{~g})$ by Ugwu and Oranye [15] but higher than the value $(0.76 \pm 0.01 \mathrm{mg} / 100 \mathrm{~g})$ reported by Osabor et al. [27]. The low level of phytic acid in the raw ABFS suggests that the nutritive value of the raw seed will be less impaired. For the Trypsin Inhibitor content of the samples, the control sample (raw ABFS) had the highest Trypsin inhibitor content of $11.26 \pm 0.02 \mathrm{Tiu} / \mathrm{mg}$ than the Alum and Trona processed samples. Samples steeped in 2.0\% Alum solution for 24 hours and cooked with $2.0 \%$ Trona concentration for 90 minutes had the least Trypsin inhibitor content of $1.64 \pm 0.02 \mathrm{Tiu} / \mathrm{mg}$. A further reduction in these antinutrients was observed in the ABFS samples cooked with Trona (Table 3). This is an indication that Trona might have facilitated the reduction of the levels of these antinutrients in the ABFS samples. Oyetayo and Omenwa [16] reported similar results for phytate, tannin and cyanide but the mechanism behind this is not yet known but it could be that Trona being a catalyst had aided in the breaking down the cell wall causing leaching thereby facilitates the reduction of these antinutrients.

\section{Conclusion}

This study has shown that processing African breadfruit seed with Alum and Trona had positive effect on its nutritional and antinutritional properties. The result showed that steeping African breadfruit seed in the Alum concentration enhanced seed dehulling but resulted in hardening of the cotyledon which was soften by the Trona added during cooking which enhanced the nutritional composition of ABFS by lowering the antinutritional factors present in the raw ABFS. The studied anti-nutritional factors of the processed ABFS samples decreased in comparison with raw seeds. This may imply improved nutrient value or quality of the ABFS. Boiling and cooking are thermal processes, hence the resultant heat may have inactive these antinutrients. In general, the degree of improvement in the nutritive value affected by steeping and cooking is dependent on the duration of each of the processing method. Of the various processing methods, cooking in $2.0 \%$ Trona seems to be best for the elimination/reduction of all the antinutritional factors investigated. 


\section{References}

[1]. J.O. Osuji and S.D. Owei, Mitotic index studies on Treculia African Decne in Nigeria. Australian Journal of Agricultural Engineering 1(1): 25-28, 2010.

[2]. E.U. Okonkwo and O.N. Ubani, Application of HACCP to post-harvest processing of African breadfruit Treculia african Decne in Nigeria. African Journal of Agricultural Research 7 (32):4536, 2012.

[3]. G.I.O.Badifu and P.I. Akubor, Influence of $\mathrm{pH}$ and sodium chloride on selected functional and physical properties of African breadfruit (Treculia africana Decne) kernel flour. Plant Foods for Human Nutrition 56: 105-115, 2001.

[4]. F.M. Ugwu, F.C. Ekwu and I.C. Okoye, Protein quality indices and food intake pattern of parboiled and roasted breadfruit-corn diets. Journal of Science, Agricultural, Food Technology and Environs. 2: 97-100, 2001.

[5]. E. Nwokolo, African breadfruit (Treculia africana Decne), and polynesian breadfruit (Artocarpus altilis Fosbery). In: nwokolo, e. and smarth, j. Edition, Legumes and oilseeds in nutrition, Chapman and Hall London. pp. 345 - 354, 1996.

[6]. H. Agu, J.A. Ayo, A.M. Paul and F. Folorunsho, Quality characteristics of biscuits made from wheat and African breadfruit (Treculia africana). Nig. Food Journal 25 (2): $19-27,2007$

[7]. I.I. Ijeh, C.E. Ejike, O.M. Nkwonta and B.C. Njoku, Effect of traditional processing techniques on the nutritional and phytochemical composition of African breadfruit (Treculia africana) seeds. Journal of Applied Sci. Environmental Management, 14(4):169-173, 2010 .

[8]. J.C. Onweluzo and O.M. Nnamuchi, Production and evaluation of porridge-type breakfast product from Treculia africana and sorghum bicolor flours. Pakistan Journal of Nutrition 8 (6): 731-736, 2009.

[9]. Y.G. Sunday, N.A. Mattew, O.A. Monday and N.E. Juliet, Compositional, functional and storage properties of flours of raw and heat processed African breadfruit (Treculia africana) seeds. Plant Foods for Human Nutrition. 55:357-368, 2000.

[10]. J.C. Onyekwelu and O.J. Fayose, Effect of storage methods on the germination and proximate composition of Treculia africana seeds. Conference on international Agricultural Research for Development, University of Kassel-witzenhausen and University of Göttingen, October 9-11, 2007.

[11]. T.U. Nwabueze and C. Nwokenna, Inter- relationship of physical and physico-chemical parameters to cooking time of African Breadfruit (Treculia africana) seeds. Journal of Food Agricultural Environment 4 (3and 4): 84-88, 2006.

[12]. P.I. Akubor, P.C. Isolukwu, O. Ugbabe and I.A. Onimawo, Proximate composition and functional properties of African breadfruit kernel and wheat flour blends. Food Research International Journal 33: 707-712, 2000.

[13]. A.A. Olapade and O.C. Aworh, Chemical and nutritional evaluation of extruded complementary foods from blends of fonio (Digitaria exilis stapf) and cowpea (Vigna unguiculata 1 walp) flours. International Journal of Food and Nutrition Sciences. 1 (3):4-8, 2012 .

[14]. O.S. Fasasi, A.F. Eleyinmi, A.R. Fasasi and O.I. Karim, Chemical properties of raw and processed breadfruit (Treculia africana) seed flour. African Crop Science and Proc. 6:547 - 551, 2003.

[15]. F.M. Ugwu and N.A. Oranye, Effects of some processing methods on the toxic components of African breadfruit (Treculia africana). African Journal of Biotechnology. 5 (22): 2329-2333, 2006.

[16]. V.O. Oyetayo and V.C. Omenwa, Microbial and chemical qualities of raw and trona processed African breadfruit (Treculia africana Decne). American Journal of Food and Tech (1):77-80, 2006.

[17]. S.G. Uzogara, I.D. Morton and J.W. Daniel, Thiamin, riboflavin and niacin retention in cooked cowpea as affected by 'kanwa' treatment. Journal of Food Science 56 (2): 592-593, 1991.

[18]. B.J.O. Efiuvwevwere and C.F. Ezeama, Influence of fermentation time and an indigenous tenderizer (kanwa) on the microbial profile, chemical attributes and shelf-life of rice 'masa'(a Nigerian fermented product). Journal of Science Food and Agriculture 71 : $442-448,1996$.

[19]. C.F. Nwankwo, B.C. Ijioma and N.C. Ihediohanma, Effect of alum on the proximate composition of raw African breadfruit (Treculia africana). Journal of Agriculture and Social Research, 7 (1): 2007.

[20]. N.E. Obasi and C.O. Wogu, Effect of soaking time on proximate and mineral compositions and anti-nutritional factors of yellow maize (zea mays). Nigerian Food Journal 26 (2): 69 - 77, 2008.

[21]. D.E. Okwu, The phytochemical and vitamin content of indigenous species of south eastern Nigeria leaves. Journal of Sustained Agriculture and Environment. 6:30-34, 2004.

[22]. D.E. Okwu and C.U. Ndu, Evaluation of the phyto-nutrients, minerals and vitamin content of some varieties of yam (Dioscorea spp). International Journal of Molecular Medicine and Advanced Sciences. 2(2): 199 -203, 2006.

[23]. I.E. Mbaeyi and J.C. Onweluzo, Effect of sprouting and pre-gelatinization on the physicochemical properties of sorghum-pigeon pea composite blend used for production of breakfast cereal. Journal of Tropical Agriculture Food, Environment and Extension. 9 (1): 8 17,2010 .

[24]. AOAC Official method of analysis, $14^{\text {th }}$ edition, Association of Official Analytical Chemists Washington DC, USA, 1990.

[25]. M.I. Kakade, J.J. Rackis, J.E. Mcghoe and G. Puski, Determination oh trypsin inhibition activity of soy products. A collaborative analysis of an improved procedure. Cereal Chemistry. 51:376, 1974.

[26]. I.C. Obizoba and H. Egbuna, Effect of germination and fermentation on the nutritional quality of bambara nut (Voandzeia subteranea L. Thouars) and its product (milk). Food Plants for Human Nutrition 41: 1-10, 1991.

[27]. V.N. Osabor, D.A. Ogar, P.C. Okafor and G.E. Egbung, Profile of the African breadfruit (Treculia africana). Pakistan Journal of Nutrition. 8 (7): 1005-1008, 2009.

[28]. O.M. David and E.Y. Aderibigbe, Microbiology and proximate composition of 'ogiri', a pastry production from different melon seeds. New York Science Journal 3(4): 18 -27, 2010.

[29]. E.O. Adeparusi, Effect of processing on some minerals, antinutrients and nutritional composition of African yam bean. Journal of Subsistence Agric and Environment 3(1):101-108, 2001.

[30]. A.I. Onimawo and K.M. Egbekun, Comprehensive food science and nutrition, revised edition, ambik press limited, Benin city, Edo State Nigeria pp. $32-51 ; 87,1998$.

[31]. B.O. Omafuvbe and O.O. Ayedapo, Biochemical changes during natural fermentation of African oil bean (Pentaclethra macrophylla) seeds. Nig. Journal of Nutrition Sci. 21:19-23, 2000.

[32]. B.O. Omafuvbe, O.O. Shonukan and S.H. Abiose, Microbiological changes in fermentation of soybean for 'soy-daddawa'- a Nigerian food condiment. Food Microbiology 17: 469 - 474, 2000.

[33]. T.H. Gadaga, L.K. Nyanga and A.N. Mutukumira, The occurrence, growth and control of pathogens in African fermented foods. African Journal of Food, Agriculture, Nutrition and Development 4 (1): 20 - 23, 2004.

[34]. F.M.S. Badejo, Introduction to food science and technology, i/c Kitamas academic and industrial publishers, Ilorin, Kwara State Nigeria. pp. 105-108; $115-122,1999$. 
[35]. J.N. Nwosu, C.I. Owuamanam, N. Onuegu, C.C. Ogueke and M. Ojukwu, The anti-nutritional properties of African yam bean (Sphenostylis sternocarpa) as affected by chemical,. International Journal of Life Sciences, 1 (3):79- 86, 2012.

[36]. C. Ikemefuna, J. Obizoba and J.V. Atii, Effects of soaking, sprouting, fermentation and cooking on nutrient composition and some antinutritional factors of sorghum (guinesia) seeds. Plant Foods for Human Nutrition 41: 203-212, 1991.

[37]. A.I. Onimawo and P.I. Akubo, Food Chemistry: integrated approach with biochemical background, published by Ambik press limited, Benin city, Edo State Nigeria. pp. 222 - 228, 2005.

Table 1: Mineral contents of the raw and processed African Breadfruit

\begin{tabular}{|c|c|c|c|c|c|c|c|c|c|}
\hline $\begin{array}{l}\text { ABFS } \\
\text { Samples }\end{array}$ & $\begin{array}{l}\text { Sodium } \\
(\mathrm{mg} / 100 \mathrm{~g})\end{array}$ & $\begin{array}{l}\text { Potassium } \\
(\mathrm{mg} / 100 \mathrm{~g})\end{array}$ & $\begin{array}{l}\text { Calcium } \\
(\mathrm{mg} / 100 \mathrm{~g})\end{array}$ & $\begin{array}{l}\text { Phosphorus } \\
\text { (mg/100g) }\end{array}$ & $\begin{array}{l}\text { Magnesium } \\
(\mathrm{mg} / 100 \mathrm{~g})\end{array}$ & $\begin{array}{c}\text { Iron } \\
(\mathrm{mg} / 100 \mathrm{~g})\end{array}$ & $\begin{array}{c}\text { Zinc } \\
(\mathrm{mg} / 100 \mathrm{~g})\end{array}$ & $\begin{array}{c}\text { Copper } \\
(\mathrm{mg} / 100 \mathrm{~g})\end{array}$ & $\begin{array}{l}\text { Manganese } \\
(\mathrm{mg} / 100 \mathrm{~g})\end{array}$ \\
\hline $\mathrm{ABF}$ & $386.60 \pm 0.02^{b}$ & $570.19 \pm 0.03^{b}$ & $6.35 \pm 0.01^{b}$ & $588.45 \pm 0.02^{b}$ & $2.40 \pm 0.02^{\mathrm{bc}}$ & $2.70 \pm 0.02^{b}$ & $8.59 \pm 0.01^{\mathrm{c}}$ & $3.75 \pm 0.02^{b}$ & $3.44 \pm 0.01^{\mathrm{b}}$ \\
\hline $\mathrm{ABK}$ & $390.41 \pm 0.03^{\mathrm{a}}$ & $588.62 \pm 0.02^{\mathrm{a}}$ & $6.41 \pm 0.02^{\mathrm{a}}$ & $590.64 \pm 0.02^{\mathrm{a}}$ & $2.45 \pm 0.01^{\mathrm{a}}$ & $2.76 \pm 0.03^{\mathrm{a}}$ & $8.68 \pm 0.02^{\mathrm{a}}$ & $3.86 \pm 0.03^{\mathrm{a}}$ & $3.49 \pm 0.01^{\mathrm{a}}$ \\
\hline $\mathrm{ABR}$ & $381.64 \pm 0.01^{\mathrm{d}}$ & $556.31 \pm 0.00^{\mathrm{c}}$ & $6.27 \pm 0.01^{\mathrm{c}}$ & $486.05 \pm 0.02^{\mathrm{d}}$ & $2.41 \pm 0.01^{\mathrm{b}}$ & $2.53 \pm 0.02^{\mathrm{cd}}$ & $8.49 \pm 0.01^{\mathrm{d}}$ & $3.61 \pm 0.03^{c}$ & $3.44 \pm 0.01^{\mathrm{b}}$ \\
\hline ABS & $374.18 \pm 0.00^{\mathrm{e}}$ & $553.66 \pm 0.01^{\mathrm{d}}$ & $6.23 \pm 0.02^{\mathrm{d}}$ & $485.50 \pm 0.02^{\mathrm{e}}$ & $2.38 \pm 0.02^{\mathrm{d}}$ & $2.51 \pm 0.01^{\mathrm{de}}$ & $8.46 \pm 0.02^{\mathrm{e}}$ & $3.63 \pm 0.01^{\mathrm{c}}$ & $3.41 \pm 0.01^{\mathrm{c}}$ \\
\hline $\mathrm{ABT}$ & $370.03 \pm 0.01^{\mathrm{f}}$ & $550.80 \pm 0.02^{\mathrm{e}}$ & $6.24 \pm 0.01^{\mathrm{cd}}$ & $480.61 \pm 0.02^{\mathrm{f}}$ & $2.36 \pm 0.02^{\mathrm{d}}$ & $2.51 \pm 0.02^{\mathrm{de}}$ & $8.45 \pm 0.02^{\text {ef }}$ & $3.60 \pm 0.01^{\mathrm{c}}$ & $3.40 \pm 0.01^{\mathrm{c}}$ \\
\hline $\mathrm{ABK}^{1}$ & $384.01 \pm 0.02^{\mathrm{c}}$ & $546.41 \pm 0.02^{\mathrm{f}}$ & $5.99 \pm 0.01^{\mathrm{e}}$ & $563.92 \pm 0.02^{\mathrm{c}}$ & $2.41 \pm 0.01^{\mathrm{b}}$ & $2.55 \pm 0.01^{\mathrm{c}}$ & $8.61 \pm 0.02^{b}$ & $2.63 \pm 0.01^{\mathrm{d}}$ & $3.03 \pm 0.02^{\mathrm{d}}$ \\
\hline $\mathrm{ABR}^{1}$ & $369.20 \pm 0.02^{\mathrm{g}}$ & $521.43 \pm 0.02^{\mathrm{g}}$ & $5.96 \pm 0.02^{\mathrm{f}}$ & $458.28 \pm 0.02^{\mathrm{g}}$ & $1.95 \pm 0.01^{\mathrm{e}}$ & $2.52 \pm 0.02^{\mathrm{de}}$ & $8.45 \pm 0.01^{\text {ef }}$ & $2.51 \pm 0.02^{\mathrm{e}}$ & $2.98 \pm 0.02^{\mathrm{e}}$ \\
\hline $\mathrm{ABS}^{1}$ & $366.61 \pm 0.03^{\mathrm{h}}$ & $520.59 \pm 0.01^{\mathrm{h}}$ & $5.94 \pm 0.01^{\mathrm{f}}$ & $455.35 \pm 0.01^{\mathrm{h}}$ & $1.91 \pm 0.01^{\mathrm{f}}$ & $2.49 \pm 0.02^{\mathrm{e}}$ & $8.43 \pm 0.02^{f}$ & $2.48 \pm 0.01^{\mathrm{f}}$ & $2.96 \pm 0.01^{\mathrm{e}}$ \\
\hline $\mathrm{ABT}^{1}$ & $365.84 \pm 0.03^{\mathrm{i}}$ & $511.23 \pm 0.03^{\mathrm{i}}$ & $5.91 \pm 0.02^{\mathrm{g}}$ & $452.56 \pm 0.03^{\mathrm{i}}$ & $1.90 \pm 0.01^{\mathrm{f}}$ & $2.44 \pm 0.02^{\mathrm{f}}$ & $8.40 \pm 0.01^{\mathrm{g}}$ & $2.41 \pm 0.01^{\mathrm{g}}$ & $2.94 \pm 0.02^{\mathrm{f}}$ \\
\hline
\end{tabular}

Values are mean of the samples \pm Standard Deviation of the Triplicates Determination. Values with different Superscript letter along the same column are significantly different $(\mathrm{P}<0.5)$ using Duncan Multiple Range Test.

ABFS $=$ African Breadfruit Seeds

Sample ABF $=$ Raw, Dehulled ABFS, (Control sample).

Sample ABK $=0 \%$ Alum steeped, parboiled and dehulled ABFS.

Sample ABR $=1.0 \%$ Alum steeped, parboiled and dehulled ABFS.

Sample ABS $=1.5 \%$ Alum steeped, parboiled and dehulled ABFS.

Sample ABT $=2.0 \%$ Alum steeped, parboiled and dehulled ABFS.

Sample $\mathrm{ABK}^{1}=0.0 \%$ Alum steeped, parboiled, dehulled and $0.0 \%$ Trona cooked ABFS.

Sample $\mathrm{ABR}^{1}=1.0 \%$ Alum steeped, parboiled, dehulled and $1.0 \%$ Trona cooked ABFS.

Sample $\mathrm{ABS}^{1}=1.5 \%$ Alum steeped, parboiled, dehulled and $1.5 \%$ Trona cooked ABFS.

Sample $\mathrm{ABT}^{1}=2.0 \%$ Alum steeped, parboiled, dehulled and $2.0 \%$ Trona cooked ABFS.

Table 2: Vitamin contents of the raw and processed African Breadfruit seed samples

\begin{tabular}{llcccc}
\hline $\begin{array}{l}\text { ABFS } \\
\text { Samples }\end{array}$ & $\begin{array}{c}\text { Vitamin A } \\
(\mu \mathrm{g} / 100 \mathrm{~g})\end{array}$ & $\begin{array}{c}\text { Vitamin } \mathrm{B}_{1} \\
(\mathrm{mg} / 100 \mathrm{~g})\end{array}$ & $\begin{array}{c}\text { Vitamin } \mathrm{B}_{2} \\
(\mathrm{mg} / 100 \mathrm{~g})\end{array}$ & $\begin{array}{c}\text { Vitamin B }_{3} \\
(\mathrm{mg} / 100 \mathrm{~g})\end{array}$ & $\begin{array}{c}\text { Vitamin C } \\
(\mathrm{mg} / 100 \mathrm{~g})\end{array}$ \\
\hline $\mathrm{ABF}$ & $20.37 \pm 0.01^{\mathrm{b}}$ & $0.20 \pm 0.01^{\mathrm{b}}$ & $12.45 \pm 0.01^{\mathrm{d}}$ & $18.15 \pm 0.02^{\mathrm{c}}$ & $2.29 \pm 0.01^{\mathrm{d}}$ \\
$\mathrm{ABK}$ & $20.74 \pm 0.02^{\mathrm{a}}$ & $0.24 \pm 0.02^{\mathrm{a}}$ & $12.73 \pm 0.02^{\mathrm{a}}$ & $18.36 \pm 0.02^{\mathrm{a}}$ & $2.48 \pm 0.02^{\mathrm{a}}$ \\
$\mathrm{ABR}$ & $20.07 \pm 0.07^{\mathrm{c}}$ & $0.19 \pm 0.01^{\mathrm{bc}}$ & $12.67 \pm 0.01^{\mathrm{b}}$ & $18.33 \pm 0.02^{\mathrm{ab}}$ & $2.38 \pm 0.01^{\mathrm{b}}$ \\
$\mathrm{ABS}$ & $19.66 \pm 0.02^{\mathrm{d}}$ & $0.18 \pm 0.00^{\mathrm{c}}$ & $12.64 \pm 0.00^{\mathrm{c}}$ & $18.32 \pm 0.01^{\mathrm{b}}$ & $2.33 \pm 0.03^{\mathrm{c}}$ \\
$\mathrm{ABT}$ & $19.01 \pm 0.00^{\mathrm{e}}$ & $0.15 \pm 0.02^{\mathrm{de}}$ & $12.35 \pm 0.03^{\mathrm{e}}$ & $18.30 \pm 0.01^{\mathrm{b}}$ & $2.30 \pm 0.01^{\mathrm{cd}}$ \\
$\mathrm{ABK}^{1}$ & $18.32 \pm 0.02^{\mathrm{f}}$ & $0.17 \pm 0.01^{\mathrm{cd}}$ & $3.83 \pm 0.02^{\mathrm{f}}$ & $16.55 \pm 0.02^{\mathrm{d}}$ & $1.880 .02^{\mathrm{e}}$ \\
$\mathrm{ABR}^{1}$ & $15.42 \pm 0.02^{\mathrm{g}}$ & $0.14 \pm 0.02^{\mathrm{e}}$ & $3.61 \pm 0.01^{\mathrm{g}}$ & $15.84 \pm 0.02^{\mathrm{c}}$ & $1.87 \pm 0.02^{\mathrm{e}}$ \\
$\mathrm{ABS}^{1}$ & $15.08 \pm 0.02^{\mathrm{h}}$ & $0.14 \pm 0.01^{\mathrm{e}}$ & $3.40 \pm 0.01^{\mathrm{h}}$ & $15.61 \pm 0.01^{\mathrm{b}}$ & $1.81 \pm 0.03^{\mathrm{f}}$ \\
$\mathrm{ABT}^{1}$ & $14.84 \pm 0.03^{\mathrm{i}}$ & $0.11 \pm 0.01^{\mathrm{f}}$ & $2.99 \pm 0.02^{\mathrm{i}}$ & $15.03 \pm 0.02^{\mathrm{g}}$ & $1.77 \pm 0.02^{\mathrm{g}}$ \\
\hline
\end{tabular}

Values are mean of the samples \pm Standard Deviation of the Triplicates Determination. Values with different Superscript letter along the same column are significantly different $(\mathrm{P}<0.5)$ using Duncan Multiple Range Test.

ABFS $=$ African Breadfruit Seeds

Sample ABF $=$ Raw, Dehulled ABFS, (Control sample).

Sample ABK $=0 \%$ Alum steeped, parboiled and dehulled ABFS.

Sample ABR $=1.0 \%$ Alum steeped, parboiled and dehulled ABFS.

Sample ABS $=1.5 \%$ Alum steeped, parboiled and dehulled ABFS.

Sample ABT $=2.0 \%$ Alum steeped, parboiled and dehulled ABFS.

Sample $\mathrm{ABK}^{1}=0.0 \%$ Alum steeped, parboiled, dehulled and $0.0 \%$ Trona cooked ABFS.

Sample $\mathrm{ABR}^{1}=1.0 \%$ Alum steeped, parboiled, dehulled and 1.0\% Trona cooked ABFS.

Sample $\mathrm{ABS}^{1}=1.5 \%$ Alum steeped, parboiled, dehulled and $1.5 \%$ Trona cooked ABFS. 
Sample $\mathrm{ABT}^{1}=2.0 \%$ Alum steeped, parboiled, dehulled and 2.0\% Trona cooked ABFS.

Table 3: Antinutritional factors of raw and processed African Breadfruit seed samples

\begin{tabular}{lccccc}
\hline $\begin{array}{l}\text { ABFS } \\
\text { Samples }\end{array}$ & $\begin{array}{c}\text { Oxalate } \\
(\%)\end{array}$ & $\begin{array}{c}\text { Tannin } \\
(\%)\end{array}$ & $\begin{array}{c}\text { Saponin } \\
(\%)\end{array}$ & $\begin{array}{c}\text { Hydrogen } \\
\text { Cyanide } \\
(\%)\end{array}$ & $\begin{array}{c}\text { Phytate } \\
(\%)\end{array}$ \\
\hline ABF & $0.21 \pm 0.01^{\mathrm{a}}$ & $0.06 \pm 0.01^{\mathrm{a}}$ & $0.47 \pm 0.01^{\mathrm{a}}$ & $1.34 \pm 0.02^{\mathrm{a}}$ & $1.85 \pm 0.02^{\mathrm{a}}$ \\
ABK & $0.16 \pm 0.05^{\mathrm{b}}$ & $0.02 \pm 0.01^{\mathrm{b}}$ & $0.22 \pm 0.01^{\mathrm{d}}$ & $1.08 \pm 0.01^{\mathrm{b}}$ & $1.77 \pm 0.02^{\mathrm{b}}$ \\
ABR & $0.15 \pm 0.01^{\mathrm{b}}$ & $0.02 \pm 0.00^{\mathrm{b}}$ & $0.22 \pm 0.00^{\mathrm{d}}$ & $1.06 \pm 0.02^{\mathrm{b}}$ & $1.74 \pm 0.01^{\mathrm{c}}$ \\
ABS & $0.15 \pm 0.01^{\mathrm{b}}$ & $0.01 \pm 0.01^{\mathrm{b}}$ & $0.22 \pm 0.02^{\mathrm{d}}$ & $1.07 \pm 0.01^{\mathrm{b}}$ & $1.76 \pm 0.02^{\mathrm{a}}$ \\
ABT & $0.14 \pm 0.01^{\mathrm{b}}$ & $0.01 \pm 0.01^{\mathrm{b}}$ & $0.22 \pm 0.05^{\mathrm{d}}$ & $1.07 \pm 0.01^{\mathrm{b}}$ & $1.70 \pm 0.02^{\mathrm{bc}}$ \\
ABK $^{1}$ & $0.13 \pm 0.02^{\mathrm{b}}$ & $0.02 \pm 0.01^{\mathrm{b}}$ & $0.24 \pm 0.01^{\mathrm{c}}$ & $0.07 \pm 0.01^{\mathrm{c}}$ & $1.07 \pm 0.02^{\mathrm{b}}$ \\
ABR $^{1}$ & $0.14 \pm 0.01^{\mathrm{b}}$ & $0.02 \pm 0.02^{\mathrm{b}}$ & $0.25 \pm 0.01^{\mathrm{bc}}$ & $0.04 \pm 0.02^{\mathrm{d}}$ & $1.71 \pm 0.01^{\mathrm{d}}$ \\
ABS $^{1}$ & $0.13 \pm 0.01^{\mathrm{b}}$ & $0.02 \pm 0.01^{\mathrm{b}}$ & $0.25 \pm 0.05^{\mathrm{bc}}$ & $0.02 \pm 0.01^{\mathrm{de}}$ & $2.24 \pm 0.02^{\mathrm{d}}$ \\
ABT $^{1}$ & $0.14 \pm 0.05^{\mathrm{b}}$ & $0.01 \pm 0.00^{\mathrm{b}}$ & $0.25 \pm 0.01^{\mathrm{b}}$ & $0.01 \pm 0.01^{\mathrm{e}}$ & $1.96 \pm 0.02^{\mathrm{g}}$ \\
\hline
\end{tabular}

Values are mean of the samples \pm Standard Deviation of the Triplicates Determination. Values with different Superscript letter along the same column are significantly different $(\mathrm{P}<0.5)$ using Duncan Multiple Range Test.

ABFS $=$ African Breadfruit Seeds

Sample ABF $=$ Raw, Dehulled ABFS, (Control sample).

Sample ABK $=0 \%$ Alum steeped, parboiled and dehulled ABFS.

Sample ABR $=1.0 \%$ Alum steeped, parboiled and dehulled ABFS.

Sample ABS $=1.5 \%$ Alum steeped, parboiled and dehulled ABFS.

Sample ABT $=2.0 \%$ Alum steeped, parboiled and dehulled ABFS.

Sample $\mathrm{ABK}^{1}=0.0 \%$ Alum steeped, parboiled, dehulled and $0.0 \%$ Trona cooked ABFS.

Sample $\mathrm{ABR}^{1}=1.0 \%$ Alum steeped, parboiled, dehulled and $1.0 \%$ Trona cooked ABFS.

Sample $\mathrm{ABS}^{1}=1.5 \%$ Alum steeped, parboiled, dehulled and $1.5 \%$ Trona cooked ABFS.

Sample $\mathrm{ABT}^{1}=2.0 \%$ Alum steeped, parboiled, dehulled and $2.0 \%$ Trona cooked ABFS. 